\title{
Potential for entry and establishment in New Zealand of Tilletia indica, the cause of Karnal bunt of wheat
}

\author{
M.V. Marroni ${ }^{1,2}$, H. Brown ${ }^{1}$ and S.L.H. Viljanen-Rollinson ${ }^{1,2}$ \\ ${ }^{1}$ The New Zealand Institute for Plant \& Food Research Ltd, Private Bag 4704, Christchurch, \\ New Zealand \\ ${ }^{2}$ Better Border Biosecurity, New Zealand \\ Corresponding author: virginia.marroni@plantandfood.co.nz
}

\begin{abstract}
Karnal or partial bunt, caused by the smut fungus Tilletia indica is a disease of wheat (Triticum aestivum and T. durum) and triticale ( $\mathrm{x}$ Triticosecale). It is listed as a quarantine pest in a large number of countries, including New Zealand. Strict phytosanitary measures are in place in New Zealand and offshore to prevent T. indica from entering the country. However, they may not be strict enough to prevent undetected contamination of grain or other traded goods via potential entry pathways. This study used climatic indices generated by two meteorological models to indicate that climatic conditions in wheat-growing regions of New Zealand are suitable for the establishment of T. indica. Establishment of T. indica on wheat may have a significant effect on grain quality and restrict trade of grain or grain products. The exclusion of the pathogen through improved border measures is the most cost-effective way to minimise the likelihood of T. indica introduction.
\end{abstract}

Keywords biosecurity, incursion, CLIMEX, Humid Thermal Index.

\section{INTRODUCTION}

Karnal or partial bunt, caused by the smut fungus Tilletia indica Mitra, is a disease of wheat (Triticum aestivum and T. durum) and triticale ( $\mathrm{x}$ Triticosecale). Tilletia indica was first reported in 1930 in Karnal, Haryana, northern India (Mitra 1931), where the pathogen is now considered to be widespread in the northern and central parts of the country (Sharma et al. 2004). In 1972, Karnal bunt was reported in Mexico, where the disease was initially confined to the Yaqui and Mayo valleys within the state of Sonora and found only in trace amounts in farmers' fields. However, in the early 1980s, disease surveys in these valleys found Karnal bunt on $64 \%$ of the farms (Rush et al. 2005). In 1996, Karnal bunt was found in a seed sample in Arizona (Ykema et al. 1996) and has since been detected in Arizona, California and Texas. Tilletia indica was reported in the state of Rio Grande do Sul in Brazil in 1993 (Da Luz et al. 1993). In 2000, T. indica was reported in the Cape Province in South Africa (Crous et al. 2001). Since then it has spread to a number of new areas in that country despite the implementation of eradication measures (Naude 2002). The pathogen is listed as a quarantine pest in a large number of countries, including New Zealand, Australia and countries within the European Union.

In the year to June 2012, a total of 488,614 tonnes of wheat was harvested in New Zealand, of which $89.3 \%$ was in the Canterbury region of the South Island. The regions of Southland and 
Otago, also in the South Island, contributed 4.6\% and 3.2\% respectively, while in the North Island, the Manawatu-Wanganui region contributed $2.1 \%$ to the total wheat harvest. (Statistics New Zealand 2014). While some wheat grain and by-products of flour milling, bran and pollard, are used for stock feed, New Zealand wheat is primarily grown for milling for domestic human consumption. The consequences of $T$. indica imparting undesirable odours and flavours in flour would therefore be severe to the industry. The potential entry pathways and the likelihood of establishment of T. indica into New Zealand were analysed, and approaches that can be taken to avoid an incursion discussed.

\section{THE DISEASE CYCLE}

Teliospores of $T$. indica are tolerant to a range of adverse environmental conditions and survive in the soil for approximately 5 years (Chahal \& Mathur 1992). Fresh teliospores usually have a period of dormancy before they are able to germinate and only those on or very near to the soil surface will break dormancy. Germinating teliospores produce promycelia containing large numbers of primary sporidia. Primary sporidia produce secondary sporidia on the soil surface, which are forcibly ejected under cool, moist conditions. Secondary sporidia that land on moist foliage are able to germinate and produce further secondary sporidia (Nagarajan et al. 1997), which can be dispersed by rain or wind. Sporidia that are deposited onto the flag leaf may be washed into the boot cavity or deposited directly on the emerging ear of wheat plants during susceptible stages of infection. These are considered to be between Zadok's growth stage (GS) 43 (boot just visible) and GS 69 (anthesis complete) (Zadoks et al. 1974; Nagarajan et al. 1997). Under favourable conditions T. indica can infect the developing grain through the glumes. Low to moderate temperatures and high humidity or rain are required for successful infection, while dry weather, high temperatures and bright sunshine are unfavourable (Warham 1986).

Following successful infection of developing flowers or grain, teliospores are produced within the developing kernel, usually being restricted to the pericarp layers.
Grains are usually only partially colonised and, within a wheat ear, not all grains are necessarily infected, giving the disease its alternative name of 'partial bunt' (Warham 1986).

Teliospores can remain within or on the grain and be dispersed by wind over large distances to infest seed for sowing, soil or debris, or to contaminate harvesting and grain handling equipment. They may also fall to the soil surface to continue the disease cycle in the following growing season (Stansbury \& Pretorius 2001).

\section{PATHWAYS INTO NEW ZEALAND}

The main potential pathway of entry of T. indica into New Zealand is through imports of wheat or triticale grain infected or contaminated with T. indica. Grain intended for sowing constitutes an obvious pathway, since planting infected seed in farms will almost certainly ensure introduction of the pathogen. Infected or contaminated grain intended for processing in areas where wheat or triticale is grown, or even for transport through such areas, also poses a risk (Sansford et al. 2006). Teliospores can be released during transportation and by handling operations from the port of entry to the consignment's final destination and during processing (Bonde et al. 1997; Forster \& Goates 1997).

In 2011, 312,068 tonnes of wheat were imported into New Zealand (FAOSTAT 2014). A large portion of milling wheat used in New Zealand mills, particularly in the North Island, is imported from Australia where T. indica is not known to occur (I. Lawrie, Plant \& Food Research, personal communication; FAOSTATS 2014). However, imports into New Zealand of smaller volumes of wheat grain from countries where Karnal bunt occurs are not uncommon. For example, between 2000 and 2011, 1,621 and 22,840 tonnes of wheat were imported from India and the USA, respectively, (FAOSTAT 2014) and small volumes of grain have occasionally been imported from Brazil (FAOSTAT 2014). Grain introduced from countries where $T$. indica is known to occur poses a potential risk of entry of the pathogen into New Zealand.

Wheat grain for sowing or for consumption, feed or processing can be imported into New Zealand in accordance with strict import health 
standards (155.02.05 Importation of seeds for sowing and BNZ-GCFP-PHR Importation of Grains/Seeds for Consumption, Feed or Processing Plant Health Requirements) (Ministry for Primary Industries 2014; MAF 2011). Both standards require that grain is sourced from a 'pest-free area', free from $T$. indica or from a 'pest free place of production', free from $T$. indica. These standards are similar to those in place in Australia and the European Union.

Compliance with the above phytosanitary measures should minimise the risk of $T$. indica entering New Zealand. However, interception data from the European Union (EU) supports the view that even with the phytosanitary regulations in place, the risk of entry of T. indica from countries where the pathogen occurs via this pathway is not insignificant. Several reported or suspected interceptions of T. indica on wheat imported from India into Poland and the UK, from Mexico into Italy and from the USA into Greece have been reported since 1996 (Sansford et al. 2006).

The methods used to determine presence or absence of $T$. indica from regions where the pathogen is known to occur may not be completely effective and so have implications regarding imports of grain into New Zealand and to other countries free of the pathogen. For example, to determine the $T$. indica status of an area or a place of production, the certifying authority in the USA relies on visual inspection. Detection of a 'bunted kernel' in, or associated with, a field within an area is necessary before the area is designated as 'regulated' (USDA/APHIS 2007). This method ensures only that grain is free from symptoms but not free from the pathogen, which can be present in visually nonsymptomatic infected grain or as a contaminant on the surface of grains (Sansford et al. 2006). Only grain intended for sowing is tested for freedom from the pathogen, whereas grain for milling could release air-borne teliospores that may infect crops. Given that teliospores can survive for a long period of time before infecting wheat crops to produce detectable disease, it is possible that the pathogen has spread to other regions within the USA but remains undetected to-date (Sansford et al. 2008). For example, T. indica was detected in a seed test sample in Arizona, USA in 1996, which was traced to wheat harvested in 1993, suggesting that the pathogen had been present since 1992 (Rush et al. 2005). In Australia, where $T$. indica is not known to occur, Stansbury et al. (2002) estimated that the time of first detection could range from 4-11 years following initial entry. In Europe, Murray \& Sansford (2005) concluded that initial establishment of $T$. indica would lead to localised infections, and detection would be unlikely until the pathogen had become widespread.

New Zealand requires an additional declaration to the phytosanitary certificate issued by the authority of the exporting country to ensure that the grain in a particular consignment is free from the pathogen at the time of shipment. The additional declaration requires that grain is sourced from a "Pest free area" or "Pest free place of production", free from T. indica $\mathbf{O R}$ were representatively sampled using International Seed Testing Association (ISTA) or Association of Official Seed Analysts (AOSA) guidelines and "tested for regulated pests at an approved diagnostic laboratory". Recently the European Union has acknowledged that presence of teliospores may not be excluded in negative samples characterised using the previous phytosanitary standards (Sansford et al. 2006; EFSA 2010). Current European Union standards require that testing at harvest and before shipment are conducted to detect teliospores infecting and contaminating grain imported into the EU (EFSA 2010). However, there may be still a risk of $T$. indica not being detected because of insufficient inspection and testing, and lack of rigour in the methods used by the authority responsible for the certifying exports (Sansford et al. 2006).

Teliospores of $T$. indica could also be present in the transport and handling system used for importing other plant material, grain or bulk commodities (e.g. fertiliser) (Murray \& Brenan 1998). The New Zealand phytosanitary system has methods in place to detect such contaminations. However, some contamination is likely to escape detection (Murray \& Brenan 1998; Sansford et 
al. 2006). Incursions of exotic organisms into New Zealand are inevitable, given increasing volumes of traded goods and presence of some uncontrolled pathways (Stephenson et al. 2003). The recent incursion of $P$. syringae pv. actinidiae is a prominent example resulting in very serious consequences for the kiwifruit industry.

In summary, the consequences of undetected T. indica infection or contamination of grain or other commodity imports may be further spread of the pathogen within a region, and potential movement of teliospores on grain during international trade (Sansford et al. 2006). While regulations and inspection procedures are in place offshore and in New Zealand to detect such contamination, a low incidence of T. indica in grain or teliospores as contaminants of other commodities may escape detection. There has been no research into establishing a threshold of inoculum of $T$. indica required to establish infection (Sansford et al. 2006). Therefore, the risk of occasional introductions of small numbers of teliospores remains uncertain.

\section{RISK OF ESTABLISHMENT IN NEW ZEALAND}

Given that there are potential pathways that may allow the pathogen entry into New Zealand, two models were used to determine the climatic suitability for the establishment of T. indica in New Zealand following its entry. Model descriptions, parameters used and results are described below.

\section{CLIMEX}

The regional, climate-based risk-modelling software CLIMEX (CSIRO, Brisbane, Australia and Hearne Scientific Software Pty Ltd, Melbourne, Australia) was used as a tool to enable climatic comparisons to be made by calculating the climatic similarities between locations contained in its database. This model has been extensively used to calculate climatic similarities between regions as an indication of suitability for establishment of invasive species (Pethybridge et al. 2003; Viljanen-Rollinson et al. 2006; Kriticos \& Leriche 2008).

The climate data from Bloemfontein in South Africa, where wheat is grown and where T. indica occurs, were compared with data from New Zealand. For the comparison, a composite of six variables, maximum temperature, minimum temperature, total rainfall, rainfall pattern, relative humidity and soil moisture, were used in the region matching to calculate a Composite Match Index (CMI).

The CMIs calculated for Napier, Blenheim, Christchurch and Timaru were 0.69, 0.73, 0.72 and 0.74 respectively. For Waipukurau, Gisborne, Nelson, Gore and Queenstown, the CMIs were $0.66,0.62,0.64,0.63$ and 0.61 respectively.

In terms of climatic conditions suitable for Karnal bunt development, CMIs of less than 0.7 are not considered biologically meaningful (Kriticos \& Leriche 2008). A CMI higher than 0.7, which indicates an overall good climate match and conditions for establishment and development of Karnal bunt, occurred in Christchurch and Timaru in the Canterbury region, the major wheat-growing area in New Zealand. However, results obtained with the use of this model should be interpreted carefully since distribution and establishment depends on factors other than climate (e.g. cultivar susceptibility). The Composite Match Index algorithm used by CLIMEX is based on climatic data for the entire year and the prediction may differ if the climatic conditions at only the susceptible stages of wheat are considered. In addition, some of the variables used to calculate the CMI, such as soil moisture, or the relationship between them, may not necessarily be relevant for $T$. indica.

The Climex model has been used by Kriticos \& Leriche (2008) to determine the potential distribution of Puccinia psidii in New Zealand. During that study, it was determined that the degree of climatic suitability for this pathogen in the North Island was very high, but it could also establish in parts of the South Island. Based on these studies, active monitoring in high risks sites in the North Island was suggested for $P$. psidii in New Zealand.

Future work with this model may include comparison with other regions where $T$. indica is known to occur, adjusting variables used to generate the CMI and inclusion of biological information for the pathogen (e.g. optimum temperature for growth). 


\section{The Humid Thermal Index (HTI)}

This model was developed by Jhorar et al. (1992) who established a correlation between meteorological elements and spread of Karnal bunt in Ludhiana, Punjab, India. Jhorar et al. (1992) found significant negative relationships between Karnal bunt establishment and spread, and maximum daily temperature and sunshine duration at the susceptible time leading to anthesis in wheat in India (correspond to 9th11th standard meteorological weeks (SMW)). A strong positive correlation was also observed for Relative Humidity (RH) at 1500 hours during the same period as well as for the number of rainy days in the 9th SMW. The mean maximum daily temperature and evening $\mathrm{RH}$ were the most important parameters. These data were used to develop the HTI, which is defined as the monthly average RH at 1500 hours divided by the average monthly maximum temperature for the month leading up to anthesis of wheat crops.
If the HTI is $<2.2$, the site is too hot or too dry; if HTI is $>2.2$ and $<3.3$, the site is suitable for Karnal bunt establishment and spread; if HTI is $>3.3$, the site is too cold or too wet. This model considers that the establishment of Karnal bunt is determined mainly by the climatic conditions favourable for teliospore germination, sporidial multiplication and infection during the time of wheat anthesis.

Simulations of late ('Wakanui'), intermediate ('Morph'), and early ('Conquest') wheat cultivars sown on 15 April, June, August, September or October in Lincoln, Canterbury, were conducted using the Agricultural Production Systems Simulator APSIM wheat model (Keating et al. 2003). This model predicts the timing of flowering from temperature and photoperiod data for a specific site and has cultivar-specific phenology coefficients that determine sensitivity to these data. The phenology coefficients for these cultivars were

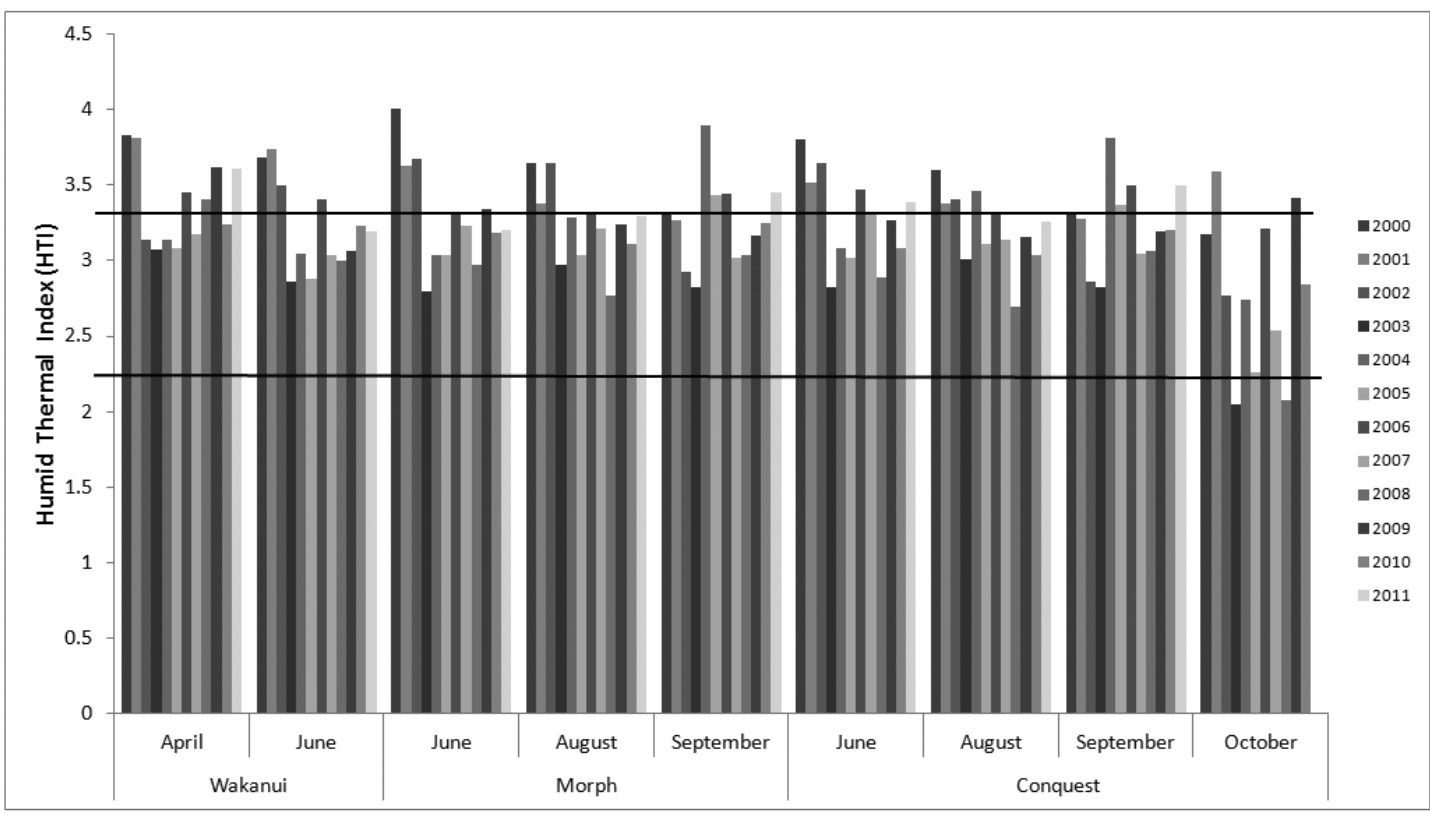

Figure 1 Humid Thermal Index (HTI) calculated during flag leaf emergence, heading and anthesis for Lincoln, Canterbury, for late ('Wakanui'), intermediate ('Morph') and early ('Conquest') wheat cultivars. Horizontal lines indicate HTI values of 2.2 and 3.3. An HTI value between 2.2 and 3.3 indicates that the site is suitable for Karnal bunt establishment and spread, while an HTI less than 2.2 indicates that the site is too hot or too dry, and an HTI greater than 3.3 indicates that the site is too cold or too wet. The month is the time of sowing of the cultivars. 
derived from flowering date observations from repeated sowing date experiments conducted in Lincoln (Brown et al. 2012). Temperature and humidity data were obtained from the NIWA National Climate Database (Clifo 2014) (Station name: Lincoln-Broadfield Ews, Agent number 17603, Network Number H32645, Lat. -43.53074 deg, Long. 172.60769 deg). Not all cultivars were included on all sowing dates since a late cultivar cannot be sown too late or an early cultivar too early. The model was set to calculate 30-day running means of maximum temperature and 1500 hours $\mathrm{RH}$, and these were used to calculate HTI. Each cultivar $\times$ sowing date scenario was simulated over 12 years (2000-2011) to provide a range of HTI values.

The HTI for early, intermediate and late wheat cultivars sown on April, June, August, September or October in Lincoln, Canterbury, showed that this region was suitable for T. indica development and infection in most years. The HTIs calculated during flag leaf emergence, heading and anthesis for these cultivars are shown in Figure 1. For the late cultivar 'Wakanui' sown in April and June, the HTI was suitable in 6 and 8 years respectively out of the 12 years considered. For the intermediate cultivar 'Morph' sown in June, August and September, the HTI was suitable in 7,8 and 7 years respectively out of the 12 years considered. For the early cultivar 'Conquest', HTI was suitable in 7 years out of the 12 years when sown in June, August and September, and in 6 years of the 11 years when it was sown in October.

The HTI in combination with the mechanistic wheat model may produce predictions that are closer to the actual situations, since this takes into account climatic data and also disease epidemiology and crop phenology factors. The HTI has been used to calculate suitability for establishment of T. indica in Australia (Murray 1998), South Africa (Stansbury 2002) and in the EU (Sansford 2006). Murray \& Brenan (1998) used this model to determine that climatic conditions were favourable for $T$. indica infection at 11 of 20 sites within the WA belt of Australia. Stansbury \& Pretorius (2001) showed that climatic conditions in the wheat growing regions of the Western Cape province of South Africa were ideally suited for T. indica development and spread.
The HTI calculated for wheat cultivars grown in Lincoln indicated that climatic conditions in wheatgrowing regions of New Zealand are suitable for the establishment of Karnal bunt. Long-term average monthly data on $\mathrm{RH}$ and temperature in the months of anthesis are available for many locations within New Zealand wheat growing regions. This model may be used in future to calculate suitability of establishment and spread of Karnal bunt in other wheat-growing regions in New Zealand, particularly in areas in the North Island, where most of the milling grain imports are destined.

\section{SUMMARY AND RECOMMENDATIONS}

Karnal bunt is considered to have minimal impact on grain yield in areas where it occurs, with yield losses generally less than 1\% (Murray \& Brennan 1998; Bonde et al. 1997). However, T. indica can greatly affect grain quality, as it imparts a fishy odour and taste to wheat flour because of the presence of trimethylamine (Singh et al. 1983), thus reducing the quality of the flour and its marketability. Grain with more than $3 \%$ bunted seeds is downgraded to animal feed in India, where susceptible cultivars grown under favourable disease conditions often exceed this percentage (Sharma et al. 2004). Under experimental conditions, susceptible European cultivars also developed an incidence of disease that exceeded the $3 \%$ infection threshold (Riccioni et al. 2008).

Indirect costs caused by $T$. indica will include testing and control costs, cost of eradication and containment, resources directed to selection for resistance programmes, and effects on export markets. Stansbury et al. (2002) estimated that the economic impact of $T$. indica introduction into Western Australia could range from 8 to $24 \%$ of the total value of wheat production. A single 50,000 ha outbreak with phytosanitary controls in the EU was estimated to cost potentially $€ 454$ million over 10 years from the time of detection (Sansford et al. 2006)

Based on the above, it is likely that successful introduction and establishment of $T$. indica in New Zealand would have a high economic impact on the wheat industry. Once introduced, the pathogen would be almost impossible to eradicate because of the likely lag period before 
detection and the fact that the spores can remain viable in the soil for 5 years or more (Chahal \& Mathur 1992).

Tilletia indica has the potential to enter, establish and cause economic damage to the New Zealand wheat industry. The strict phytosanitary measures already in place in New Zealand are the most cost-effective way to minimise the likelihood of introduction of $T$. indica. The degree of protection could be increased by a requirement for sampling and testing of all grain imported into New Zealand from countries where the pathogen is known to occur, as is currently in place in the European Union. This should be conducted at harvest and before shipment, to detect teliospores and contamination of grain.

\section{ACKNOWLEDGEMENTS}

This work was funded by Plant \& Food Research Core funding aligned to the Better Border Biosecurity (B3) programme (www.b3nz.org).

\section{REFERENCES}

Bonde MR, Peterson GL, Schaad NW, Smilanick JL 1997. Karnal bunt of wheat. Plant Disease 81: 1370-1377.

Brown H, Munro C, Huth N, Meenken E 2012. Using a crop model to characterise the developmental phenotype of different wheat varieties. Sage 11: 5.

Chahal S, Mathur S 1992. Germination of deepfrozen Tilletia indica and Tilletia barclayana teliospores. FAO Plant Protection Bulletin 40: 31-35.

CliFlo 2014. NIWA's National Climate Database on the Web. URL: http://cliflo.niwa.co.nz/ (accessed 15 April 2013).

Crous PW, Jaarsveld ABv, Castlebury LA, Carris LM, Frederick RD, Pretorius ZA 2001. Karnal bunt of wheat newly reported from the African continent. Plant Disease 85: 561-561.

Da Luz WC, Mendes MAS, Ferreira MASV, Urben AF 1993. Tilletia indica on wheat in the southern part of Rio Grande do Sul and means for its eradication. Fitopatologia Brasileira 18 (Supplement): 323.
EFSA 2010. Scientific opinion on a quantitative pathway analysis of the likelihood of Tilletia indica M. introduction into EU with importation of US wheat. EFSA Journal 8(6): 1621 (doi:10.2903/j.efsa.2010.1621).

EPPO 2014. PQR-EPPO database on quarantine pests. http://www.eppo.int (accessed 15 April 2014).

FAOSTAT 2014. Food and Agriculture Organization of the United Nations. FAOSTAT (Database) (Latest update: 07 Mar 2014). http://faostat3.fao.org/faostatgateway/go/to/download/T/*/E (accessed 15 April 2014).

Forster RL, Goates BJ 1997. Karnal bunt. http:// www.cals.uidaho.edu/edcomm/pdf/CIS/ CIS1067.pdf (accessed 28 April 2014).

Jhorar OP, MaviHS, Sharma I, MahiGS, Mathauda SS, Gurmeet S 1992. A biometeorological model for forecasting Karnal bunt disease of wheat. Plant Disease Research 7: 204-209.

Joshi L, Singh D, Srivastava K, Wilcoxson R 1983. Karnal bunt: A minor disease that is now a threat to wheat. The Botanical Review 49: 309-330.

Keating BA, Carberry PS, Hammer GL, Probert ME, Robertson MJ, Holzworth D, Huth NI, Hargreaves JN, Meinke H, Hochman Z 2003. An overview of APSIM, a model designed for farming systems simulation. European Journal of Agronomy 18: 267-288.

Kriticos DJ, Leriche A 2008. The current and future potential distribution of guava rust, Puccinia psidii in New Zealand. MAF Biosecurity New Zealand Technical Paper (2009/28). Scion, Rotorua, New Zealand.

MAF 2011. Standard BNZ-GCFP-PHR: Importation of Grains/Seeds for Consumption, Feed or Processing, 23 June 2011. http://www. biosecurity.govt.nz/files/ihs/bnz-gcfp-phr.pdf (accessed 15 April 2014).

Ministry for Primary Industries 2014. Import Health Standard 155.02.05: Importation of Seed for Sowing. http://www.biosecurity. govt.nz/files/ihs/155-02-05.pdf (accessed 15 April 2014). 
Mitra M 1931. A new bunt of wheat in India. Annals of Applied Biology 18: 178-179.

Murray GM, Brenan JP 1998. The risk to Australia from Tilletia indica, the cause of Karnal bunt of wheat. Australasian Plant Pathology 27: 212-225.

Murray G, Sansford C 2005. How Tilletia indica overcomes the Allee effect. Proceedings of the 15th Biennial Australasian Plant Pathology Society Conference. p. 256.

Nagarajan S, Aujla SS, Nanda GS, Sharma I, Goel LB, Kumar J, Singh DV 1997. Karnal bunt (Tilletia indica) of wheat - a review. Review of Plant Pathology 76: 1207-1214.

Naude K 2002. Karnal bunt in the South African wheat industry. Items from South Africa Small Grain Institute. Annual Wheat Newsletter 49: 137.

Pethybridge SJ, Nelson ME, Wilson CR 2003. Forecasting climate suitability of Australian hop-growing regions for establishment of hop powdery and downy mildews. Australasian Plant Pathology 32(4): 493-497.

Riccioni L, Inman A, Magnus HA 2008. Susceptibility of European bread and durum wheat cultivars to Tilletia indica. Plant Pathology 57: 612-622.

Rush CM, Stein JM, Bowden RL, Riemenschneider R, Boratynski T, Royer MH 2005. Status of Karnal bunt of wheat in the United States 1996 to 2004. Plant Disease 89: 212-223.

Sansford C, Baker R, Brennan J, Ewert F, Gioli B, Inman A, Kelly P, Kinsella A, Leth V, Magnus H 2006. Pest Risk Analysis for Tilletia indica for the European Union. EU Karnal Bunt Risks Project. Deliverable Report 6 1 and 6.5. http://karnalpublic.pestrisk.net/ (accessed 15 May 2014).

Sansford CE, Baker RHA, Brennan JP, Ewert F, Gioli B, Inman A, Kinsella A, Magnus HA, Miglietta F, Murray GM, Porta-Puglia A, Porter JR, Rafoss T, Riccioni L, Thorne F 2008. The new Pest Risk Analysis for Tilletia indica, the cause of Karnal bunt of wheat, continues to support the quarantine status of the pathogen in Europe. Plant Pathology 57: 603-611.
Sharma I, Nanda GS, Singh H, Sharma RC 2004. Status of karnal bunt disease of wheat in Punjab (1994-2004). Indian Phytopathology 57: 435-439.

Singh D, Joshi L, Srivastava K 1983. Karnal bunt, new threats to wheat in India. In: Hussain A, Singh K, Singh BP, Agnihotri VP ed. Recent Advances in Plant Pathology. Print House, Lucknow, India. Pp. 121-135.

Stansbury CD, Pretorius ZA 2001. Modelling the potential distribution of Karnal bunt of wheat in South Africa. South African Journal of Plant and Soil 18: 159-168.

Stansbury CD, McKirdy SJ, Diggle AJ, Riley IT 2002. Modeling the risk of entry, establishment, spread, containment, and economic impact of Tilletia indica, the cause of Karnal bunt of wheat, using an Australian context. Phytopathology 92: 321-331.

Statistics New Zealand 2014. Grain and seed crops by region. Agricultural Production Statistics. www.stats.govt.nz (accessed 15 April 2014).

Stephenson B, Gill G, Randall J, Wilson J 2003. Biosecurity approaches to surveillance and response for new plant pest species. New Zealand Plant Protection 56: 5-9.

USDA/APHIS 2007. Karnal Bunt Manual. http://www.aphis.usda.gov/import_export/ plants/manuals/domestic/downloads/kb.pdf (accessed 28 April 2014).

Viljanen-Rollinson SLH, Deng Y, Marroni MV, Cheah L-H 2006. The potential occurrence of Puccinia asparagi in New Zealand. New Zealand Plant Protection 59: 137-140.

Warham EJ 1986. Karnal bunt disease of wheat a literature review. Tropical Pest Management 32: 229-242.

Ykema RE, Palm ME, Peterson GL 1996. First report of karnal bunt of wheat in the United States. Plant Disease 80: 1207-1207.

Zadoks JC, Chang TT, Konzak CF 1974. A decimal code for the growth stages of cereals. Weed Research 14: 415-421. 